\title{
Management Techniques of Root-Knot Nematode in Tomato Crop under Protected Conditions
}

\author{
V.S. Jirvankar, U.B. Hole, R.R. Dhole* and S.K. Patil \\ Department of Agricultural Entomology, Mahatma PhuleKrishiVidyapeeth, Rahuri - 413 722, \\ Dist. Ahmednagar, Maharashtra, India \\ *Corresponding author
}

\section{A B S T R A C T}

\section{Keywords \\ Tomato, Root knot nematode, Neem cake, $P$. lilacinus \\ Article Info \\ Accepted: \\ 12 July 2018 \\ Available Online: \\ 10 August 2018}

\begin{abstract}
The present experiment was conducted under shade net house for the management of root-knot nematode infesting tomato with nine treatments including untreated control. Results revealed that all the treatments were found significantly superior over an untreated control in reducing the root-knot nematode population, number of root galls and gall index and increasing the yield of tomato at termination. However, soil application of neem cake at $200 \mathrm{~g} / \mathrm{m}^{2}{ }_{+}$Purpureocillium lilacinus at $50 \mathrm{~g} / \mathrm{m}^{2}$ was found to be more effective in reducing root-knot nematode $(\mathrm{RkN})$ population $(59.12 \%)$, number of root galls $(73.72 \%)$ and gall index $(38.00 \%)$ and increasing the yield of tomato (62.78) with ICBR ratio of 1:2.1 at termination of the experiment.
\end{abstract}

\section{Introduction}

Tomato is popularly known as "poor man's orange". Tomato (Solanum lycopersicum L.) is one of the very important fruit vegetable in India. In India, it is grown over an area of 7.91 lakh ha, with an annual production of about 173.98 lakh metric tonnes with the productivity of 22.01 metric tonnes/ha. Major tomato growing states in India are Madhya Pradesh, Karnataka and Odisha while Maharashtra stands seventh with an area of 43860 ha and production: productivity of 10.58: 24.12 lakh metric tonnes/ha. (Anonymous, 2016). Tomato fruits have high nutritional value. It is a rich source of minerals, organic acids and vitamins ' $\mathrm{A}$ ', ' $\mathrm{B}$ ' and 'C' (Tewari, 2002).

The crop is attacked by various insect and non-insect pests. In addition to insect pest and diseases, plant parasitic nematodes have also become a limiting factor in the successful cultivation of tomato. Among several plant parasitic nematodes recorded, root-knot nematode, Meloidogyne incognita is the most important one. The loss in yield of tomato due to $M$. incognita and Rotylenchusreniformis was 42.05 to 54.42 and 42.25 to 49.02 per cent, respectively (Subramaniyam et al., 1990). Besides, the direct damage caused to the plants, the root-knot nematodes are 
notorious for the disease complexes involving fungi, bacteria, virus, mycoplasma, insect and other nematodes (Dasgupta and Gaur, 1986).

The control of root-knot nematode $(\mathrm{RkN})$ has been primarily accomplished through chemical nematicides. However, indiscriminate use of these chemicals only resulted in health and environmental hazards. To avoid this, integrated management is become necessary and use of biological and botanical substances or agent in management of root knot nematode should be promoted. In view of this, the present study is undertaken with an objective of management techniques in tomato under protected condition.

\section{Materials and Methods}

\section{Studies on root-knot nematode management techniques in tomato under protected condition}

For management study, the field was plotted in randomize block design with nine treatments and three replications. The seedlings of tomato (cv. Phule Raja) grown in nursery were transplanted in a root-knot nematode infested field at $90 \times 30 \mathrm{~cm}$ spacing having $1.0 \times 5.5 \mathrm{~m}$ gross plot size. The nematode population in the field was ascertained by Cobb's Sieving and Decanting Method. The crop was grown by all recommended horticultural practices. The treatment of carbofuran 3G @ $0.6 \mathrm{~g}$ a.i. $/ \mathrm{m}^{2}$ was applied at the time of transplanting. The bioagents, $P$. fluorescens, P.lilacinus, $T$. virideat $50 \mathrm{~g} / \mathrm{m}^{2}$ were applied with FYM only in the soil at the time of transplanting. The neem cake at $200 \mathrm{~g} / \mathrm{m}^{2}$ was applied at the time of transplanting. Pre and post treatment sampling of the soil was done from the individual experimental field plot to count the nematode population before the commencement and at termination of the experiment.

\section{Method of recording observations}

The $200 \mathrm{~g}$ soil samples from the root-knot nematode sick plots were processed by Cobb's Sieving and Decanting Method in laboratory for initial and final root-knot nematode population in the plots. The residues of 200 and 350 mesh sieves were collected in plastic beaker and the volume of the beaker was adjusted to $200 \mathrm{ml}$ by adding tap water. For nematode count, the average of 10 counts of $1 \mathrm{ml}$ solution was recorded and from this it was calculated to $200 \mathrm{ml}$ of solution. From these observations percent decrease in nematode population was worked out.

At termination, ten plants from each plot were uprooted carefully and washed under clean tap water to remove the adhering soil particles to the roots. Number of galls and egg masses on roots per plant was recorded and gall indices 1-5 scale as given below were worked out. From these observations percent decrease in gall index over an untreated control was worked out.

\begin{tabular}{|l|l|}
\hline \multicolumn{2}{|l|}{ Gall index } \\
\hline Index & Symptoms \\
\hline 1. & No galls/egg masses/plant \\
\hline $\mathbf{2 .}$ & 1 to 10 galls/egg masses/plant \\
\hline 3. & 11 to 30 galls/egg masses/plant \\
\hline 4. & 31 to 100 galls/egg masses/plant \\
\hline $\mathbf{5 .}$ & $>101$ galls/egg masses/plant \\
\hline
\end{tabular}

The tomato fruit yield obtained from the plants in the plots of each treatments at each picking made at 5 days interval commencing from fifty-five days after sowing up to termination was recorded and expressed in quintals per hectare. From these observations, the percent loss and increase in yield over an untreated control was ascertained and ICBR was calculated. 


\section{Results and Discussion}

\section{Studies on root-knot nematode management techniques in tomato under protected condition}

In order to assay the effect of different treatments viz., nematicide, bioagents and organic amendment as soil application for the management of root-knot nematode $(\mathrm{RkN})$, $M$. incognita infesting tomato (cv. Phule Raja), an experiment was conducted under shade net house during kharif, 2016. The observations on initial and final population of root-knot nematode $\left(\mathrm{J}^{2}\right) / 200 \mathrm{~cm}^{3}$ of soil, number of root galls and egg masses and gall index per plant and yield per plot were recorded at the time of termination of the experiment and presented in table 1 and 2 .

The pre-treatment root-knot nematode population in the plots of field was within the range of 400 to 680 nematodes $\left(\mathrm{J}^{2}\right) / 200 \mathrm{~cm}^{3}$ of soil. It could be seen from data that all the treatments were significantly superior over an untreated control in reducing the root-knot nematode population at termination. Among all the treatments, soil application of neem cake at $200 \mathrm{~g} / \mathrm{m}^{2}+$ Purpureocilliumlilacinus at $50 \mathrm{~g} / \mathrm{m}^{2}$ was found to be most effective in reducing root-knot nematode population $(59.12 \%)$, number of root galls $(73.72 \%)$ and gall index $(38.00 \%)$ at termination.

This was followed by the treatment of soil application of neem cake at $200 \mathrm{~g} / \mathrm{m}^{2}+P$. fluorescens at $50 \mathrm{~g} / \mathrm{m}^{2}$. The reduction in rootknot nematode population $(56.84 \%)$, number of root galls/plant $(70.81 \%)$, gall index $(34 \%)$ at termination. The next in the order of effectiveness was the treatment of neem cake at $200 \mathrm{~g} / \mathrm{m}^{2}+T$. viridae at $50 \mathrm{~g} / \mathrm{m}^{2}$. The reduction in root-knot nematode population $(54.57 \%)$, number of root galls/plant (62.34\%), gall index $(29.33 \%)$ at termination.However, the treatments of soil application of neem cake at $200 \mathrm{~g} / \mathrm{m}^{2}+P$. fluorescens at $50 \mathrm{~g} / \mathrm{m}^{2}$ and neem cake at 200 $\mathrm{g} / \mathrm{m}^{2}+T$. viridae at $50 \mathrm{~g} / \mathrm{m}^{2}$ were found to be equally effective and are at par with each other in reducing root-knot nematode population number of root galls and gall index.

\section{Effect of different treatments on fruit yield} of tomato and their incremental cost benefit ratio

It is revealed from the data that all the treatments induced the significant effect on increase in the yield of tomato. Among the different treatments, soil application of neem cake at $200 \mathrm{~g} / \mathrm{m}^{2}+$ Purpureocilliumlilacinus at $50 \mathrm{~g} / \mathrm{m}^{2}$ was found to be significantly superior in recording highest fruit yield of $390.67 \mathrm{q} / \mathrm{ha}$ as agai

nst $240.00 \mathrm{q} / \mathrm{ha}$ in an untreated control. Thus 62.78 per cent increase in yield of tomato over an untreated control with 1:2.1 ICBR was recorded in this treatment.

However, the treatments of soil application of neem cake at $200 \mathrm{~g} / \mathrm{m}^{2}+P$. fluorescens at 50 $\mathrm{g} / \mathrm{m}^{2}$ and neem cake at $200 \mathrm{~g} / \mathrm{m}^{2}+T$. viride at $50 \mathrm{~g} / \mathrm{m}^{2}$ were found to be equally effective in recording yield of 378.66 and $369.81 \mathrm{q} / \mathrm{ha}$, respectively at termination.

Thus, 57.77 and 54.09 per cent increase was recorded in yield over an untreated control with $1: 1.93$ and $1: 1.81$ ICBR, respectively by these treatments.

In general, among all the treatments, neem cake at $200 \mathrm{~g} / \mathrm{m}^{2}+$ Purpureocilliumlilacinus at $50 \mathrm{~g} / \mathrm{m}^{2}$ was found to be most effective in reducing root-knot nematode $(\mathrm{RkN})$ population, number of root galls and gall index and increasing yield $(62.78 \%)$ of tomato with 1:2.1 ICBR at termination. 
Table.1 Effect of different treatments on soil population, root galls and gall index of root-knot nematode infesting tomato under protected condition

\section{Sr. Treatment}

No.

\section{Avg. RkN \\ Population \\ $\left(\mathbf{J}^{2}\right) / 200 \mathrm{~cm}^{3}$ \\ of soil}

Initial Final
Decline in

RkN

Population at

Termination

$(\%)^{*}$

34.40

(35.91)
Avg. no. of

root galls/

plant at

terminatio

n

68.98
Decline in Avg. Gall

root gall at Index per

terminatio

n

$(\%)^{*}$

42.34

(40.59) plant

\subsection{0}

Decline in gall index at terminatio $\mathbf{n}(\%)^{*}$ neem cake@200 $\mathrm{g} / \mathrm{m}^{2}$ three weeks before transplanting

2. Soil application of $P$.

fluorescens@50 g/m $\mathrm{m}^{2}$ at the time of transplanting

3. $\quad$ Soil application of $T$. $553.33 \quad 313.33 \quad 43.30$

viride@ $50 \mathrm{~g} / \mathrm{m}^{2}$ alone

(41.15)

39.46

(38.87)

at the time of transplanting

4. Soil application of $P$. lilacinus@50 g/ $\mathrm{m}^{2}$ alone at the time of transplanting

5. $\quad \mathrm{T}_{1}+$ P. fluorescens@ 566.67246 .67 $50 \mathrm{~g} / \mathrm{m}^{2}$ at the time of transplanting

6. $\quad \mathrm{T}_{1}+T$.viride@50 $\mathrm{g} / \mathrm{m}^{2}$ at the time of transplanting

7. $\quad \mathrm{T}_{1}+$ P. lilacinus@ 50600.00246 .67 $\mathrm{g} / \mathrm{m}^{2}$ at the time of transplanting

8. Carbofuran $3 \mathrm{G}$ at 0.6 g a.i. $/ \mathrm{m}^{2}$ before transplanting

9. Untreated control

580.00
566.67

360.00

. 37.2 .000

$(37.69)$

$(37.69)$

\begin{tabular}{|l|l|}
\hline 533.33 & 260.00
\end{tabular}

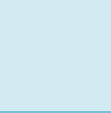

56.84

(48.94)

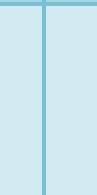

63.83

5.43

\begin{tabular}{|c|c|}
46.65 \\
$(43.08)$ \\
\end{tabular}

59.43

50.33

(45.19)

8.00

(16.35)

in
ex
tio


Table. 2 Effect of different treatments on fruit yield of tomato and their incremental cost benefit ratio for root-knot nematode management techniques in protected condition

\begin{tabular}{|c|c|c|c|c|c|c|c|}
\hline $\begin{array}{l}\text { Sr. } \\
\text { No. }\end{array}$ & Treatment & $\begin{array}{l}\text { Yield } \\
\text { (q/ha) }\end{array}$ & $\begin{array}{l}\text { Increase } \\
\text { in yield } \\
(\%)^{*}\end{array}$ & $\begin{array}{l}\text { Additional } \\
\text { yield(q/ha) }\end{array}$ & $\begin{array}{l}\text { Additional } \\
\text { income }\end{array}$ & $\begin{array}{l}\text { Addtional } \\
\text { cost }\end{array}$ & ICBR \\
\hline 1. & $\begin{array}{l}\text { Soil application of } \\
\text { neem cake @ } 200 \mathrm{~g} / \mathrm{m}^{2} \\
\text { three weeks before } \\
\text { transplanting }\end{array}$ & 258.67 & $\begin{array}{c}7.78 \\
(16.20)\end{array}$ & 18.67 & 37340 & 17000 & $1: 2.19$ \\
\hline 2. & $\begin{array}{l}\text { Soil application of } P \text {. } \\
\text { fluorescens@ @ } 50 \mathrm{~g} / \mathrm{m}^{2} \\
\text { at the time of } \\
\text { transplanting }\end{array}$ & 317.40 & $\begin{array}{c}32.25 \\
(34.60)\end{array}$ & 77.4 & 154800 & 126000 & $1: 1.22$ \\
\hline 3. & $\begin{array}{l}\text { Soil application of } T \text {. } \\
\text { viride@ } 50 \mathrm{~g} / \mathrm{m}^{2} \text { alone } \\
\text { at the time of } \\
\text { transplanting }\end{array}$ & 322.66 & $\begin{array}{c}34.44 \\
(35.93)\end{array}$ & 82.66 & 165320 & 126000 & $1: 1.31$ \\
\hline 4. & $\begin{array}{l}\text { Soil application of } P \text {. } \\
\text { lilacinus@ } 50 \mathrm{~g} / \mathrm{m}^{2} \\
\text { alone at the time of } \\
\text { transplanting }\end{array}$ & 312.16 & $\begin{array}{c}30.07 \\
(33.25)\end{array}$ & 72.16 & 144320 & 126000 & $1: 1.14$ \\
\hline 5. & $\begin{array}{l}\mathrm{T}_{1}+P . \text { fluorescens@ } \\
50 \mathrm{~g} / \mathrm{m}^{2} \text { at the time of } \\
\text { transplanting }\end{array}$ & 378.66 & $\begin{array}{c}57.77 \\
(49.47)\end{array}$ & 138.66 & 277320 & 143000 & $1: 1.93$ \\
\hline 6. & $\begin{array}{l}\mathrm{T}_{1}+T . \text { viride @ } 50 \\
\mathrm{~g} / \mathrm{m}^{2} \text { at the time of } \\
\text { transplanting }\end{array}$ & 369.81 & $\begin{array}{c}54.09 \\
(47.35)\end{array}$ & 129.81 & 259620 & 143000 & $1: 1.81$ \\
\hline 7. & $\begin{array}{l}\mathrm{T}_{1}+P . \text { lilacinus@ } 50 \\
\mathrm{~g} / \mathrm{m}^{2} \text { at the time of } \\
\text { transplanting }\end{array}$ & 390.67 & $\begin{array}{c}62.78 \\
(52.40)\end{array}$ & 150.67 & 301340 & 143000 & $1: 2.10$ \\
\hline 8. & $\begin{array}{l}\text { Carbofuran } 3 \mathrm{G} \text { at } 0.6 \mathrm{~g} \\
\begin{array}{l}\text { a.i. } / \mathrm{m}^{2} \\
\text { transplanting }\end{array}\end{array}$ & 330.81 & $\begin{array}{c}37.84 \\
(37.96)\end{array}$ & 90.81 & 181620 & 20000 & $1: 9.08$ \\
\hline 9. & Untreated control & 240.00 & $\begin{array}{c}0.00 \\
(0.00)\end{array}$ & - & - & - & - \\
\hline & S.E. + & & 3.00 & & & & \\
\hline & C.D. at $5 \%$ & & 8.99 & & & & \\
\hline & C.V. & & 12.39 & & & & \\
\hline \multicolumn{8}{|c|}{ *Figures in parentheses are arcsin transformed values } \\
\hline \multirow[t]{3}{*}{ Mark } & \multirow{3}{*}{\multicolumn{3}{|c|}{$\begin{array}{l}\text { 1. Tomato truits-Rs. } 2000 / \mathrm{q} \\
\text { 5. Carbofuran- Rs. } 100 / \mathrm{kg} \\
\text { application) }\end{array}$}} & \multicolumn{3}{|c|}{ 2. Bioagents- Rs. $250 / \mathrm{kg}$} & \\
\hline & & & & \multicolumn{3}{|c|}{ 4. Neem cake - Rs. $8 / \mathrm{kg}$} & \\
\hline & & & & & & & \\
\hline
\end{tabular}


The effectiveness of soil application of neem cake + Purpureocillium lilacinus for management of root-knot nematode $(\mathrm{RkN})$ is in conformity with that of Cannayane and Rajendran (2001) on brinjal and Rao (2008) on acid lime for the management of root-knot nematode $(\mathrm{RkN})$. The reduction in nematode population as a result of soil application of carbofuran $3 \mathrm{G}$ may be due to inhibition development of root-knot nematode $(\mathrm{RkN})$. This is in conformity with that of reported by Mahajan (1982) and Sonawane and Darekar (1985) on brinjal, Khan and Rathi (2001) on tomato and Singh (2006) on cauliflowers and Shendge (2009) on okra.

\section{References}

Anonymous. 2016. Indian Horticulture database. Ministry of Agriculture, Govt. of India.

Cannayane, I. and Rajendran, G. 2001. Application of biocontrol agents and oil cakes for the management of M.incognita in brinjal (Solanum melongena L.).Curr. Nematol., 12 (1/2): 51-55.

Dasgupta, D.R. and Gaur, H.S. 1986. The root-knot nematodes. Meloidogyne spp. in India. In: Plant Parasitic Nematodes of India. Problems and Progress [Swarup, G. and Dasgupta, D.R. (eds)] pp. 139-178.

Khan, M.L. and Rathi, R. 2001. Effect of organic amendments and carbofuran on $M$. incognita population and yield in tomato. Indian J. Nematol., 31 (1): 7998.

Mahajan, R. 1982. Efficacy of spot treatment with nematicides for the control of $M$. incognita in eggplant, Solanum melongena. Indian J. Nematol., 12 (2): 375-419.

Rao, M.S. 2008. Management of Meloidogyne javanica on acid lime using Paecilomyces lilacinus and Pseudomonas fluorescens. Nematol. Medit., 36(1): 45-50.

Shendge, G.A. 2009. Studies of assessment of yield losses and integrated management of root-knot nematode, Meloidogyne incognita (Kofoid and White, 1919) Chitwood, 1949 infesting okra (Abelmoschus esculentus L.). Thesis submitted to M.P.K.V., Rahuri.

Singh, V.K. 2006. Management of root-knot nematode, $M$. incognita infesting cauliflower. Indian J. Nematol., 36(1): 127-128.

Sonawane, M.L. and Darekar, K.S. 1985. Control of root-knot nematode, Meloidogyne incognita of eggplant with some granular nematicides. Curr. Res. Report., 1(1): 15-17.

Subramaniyan, S., Rajendran, G. and Vadivelu, S. 1990. Estimation of loss in tomato due to $M$. incognita and Rotylenchulus reniformis. Indian J. Nematol., 20 (2): 239-240.

Tewari, R.L. 2002.Handbook of Horticulture, I.C.A.R. Publication. pp. 464-470.

\section{How to cite this article:}

Jirvankar, V.S., U.B. Hole, R.R. Dhole and Patil, S.K. 2018. Management Techniques of RootKnot Nematode in Tomato Crop under Protected Conditions. Int.J.Curr.Microbiol.App.Sci. 7(08): 1951-1956. doi: https://doi.org/10.20546/ijcmas.2018.708.224 